\title{
RETURN ON ASSET, RETURN ON EQUITY, DAN EARNING PER SHARE BERPENGARUH TERHADAP RETURN SAHAM
}

\author{
Ni Putu Alma Kalya Almira ${ }^{1}$ \\ Ni Luh Putu Wiagustini ${ }^{2}$ \\ ${ }^{1,2}$ Fakultas Ekonomi dan Bisnis Universitas Udayana (Unud), Bali, Indonesia \\ email: almirakalya54@gmail.com
}

\begin{abstract}
ABSTRAK
Penelitian ini bertujuan untuk mengetahui pengaruh Return on Asset, Return on Equity, dan Earning Per share terhadap Return saham pada perusahaan Food and Baverages di Bursa Efek Indonesia periode 2015-2018. Populasi yang digunakan dalam penelitian ini adalah perusahaan Sub sektor Food and Baverages. Penelitian ini memakai sampling jenuh (Sensus) dengan jumlah sampel sebanyak 13 perusahaan. Regresi linear berganda merupakan metode yang digunakan untuk menganalisis data dalam penelitian ini. Hasil penelitian menunjukkan bahwa Return on Asset, Return on Equity dan Earning per Share berpengaruh positif signifikan terhada Return saham.
\end{abstract}

Kata Kunci : Return On Asset, Return On Equity, Return Saham, Earning Per Share

\begin{abstract}
This study aims to determine the effect of Return on Assets, Return on Equity, and Earning Per share on stock returns in the Food and Baverage companies on the Indonesia Stock Exchange in the period 2015-2018. The population used in this study is the Food and Baverages Sub-sector company. This study uses saturated sampling (census) with a total sample of 13 companies. Multiple linear regression is a method used to analyze the data in this study. The results showed that Return on Assets, Return on Equity and Earning per Share had a significant positive effect on stock returns.

Keywords: Return on Asset, Return on Equity, Stock Return, Dan Earning Per Share
\end{abstract}




\section{PENDAHULUAN}

Analisis untuk mengukur nilai saham, yaitu analisis fundamental dan analisis teknikal diperlukan melakukan investasi yang berbentuk saham. Tujuan analisis fundamental adalah menentukan apakah nilai saham berada pada posisi undervalue atau overvalue (Rumokoy \& Tamunu, 2015). Saham dikatakan undervalue bilamana return saham di pasar saham lebih kecil dari harga wajar atau nilai yang seharusnya, demikian juga sebaliknya. Dapat dikatakan bahwa untuk memperkirakan return saham dapat menggunakan analisis fundamental yang menganalisa kondisi keuangan dan ekonomi perusahaan yang menerbitkan saham tersebut (Wijesundera et al., 2016). Terdapat banyak faktor yang mempengaruhi return saham yaitu Return on Asset. Penelitian dari Sorongan (2016), Olowoniyi \& Ojenike (2012), \& Kabajeh et al. (2012) yang memperoleh hasil penelitian bahwa terdapat hubungan searah (positif) antara ROE dengan Return saham. Berbeda dengan penelitian Wahyuni (2017) yang mengemukakan bahwa ROE menunjukkan tidak berpengaruh dengan Return saham

Pada tahap analisis terhadap perusahaan dalam pendekatan fundamental, kinerja keuangan menjadi salah aspek penilaian yang harus diperhatikan. Investor dapat mengukur kinerja keuangan perusahaan menggunakan analisis rasio keuangan. Pada umumnya rasio-rasio keuangan yang digunakan untuk menilai kinerja perusahaan dilihat dalam berbagai aspek, yaitu aspek likuiditas, aspek profitabilitas, aspek solvabilitas, dan aspek aktivitas usaha dan penilaian pasar (Wiagustini, 2010:75). Penilaian kinerja keuangan suatu perusahaan dalam penelitian ini dilihat dari aspek profibilitas dan penilaian pasar terhadap perusahaan.

return merupakan hasil yang diperoleh dari sebuah investasi. return dapat berupa return realisasi (realized return) yaitu return yang telah terjadi atau return ekspektasi (expected return) yaitu return yang diharapkan terjadi di masa yang akan datang. Tujuan corporate finance adalah memaksimumkan nilai perusahaan. Tujuan ini bisa menyimpan konflik potensial antara pemilik perusahaan dengan kreditur. Saham suatu perusahaan bisa dinilai dari pengambalian (return) yang diterima oleh pemegang saham dari perusahaan yang bersangkutan. return bagi pemegang saham bisa berupa dividen tunai ataupun adanya perubahan harga saham pada satu periode.

Return on Asset mengukur kemampuan dalam menghasilkan laba dari total aktiva yang digunakan (Wiagustini, 2010:81). Setiap perusahaan berusaha agar nilai dari ROA mereka tinggi. Semakin besar nilai dari ROA itu berarti bahwa semakin baik perusahaan menggunakan assetnya untuk mendapatkan laba.

Berdasarkan Gambar 1. dapat dilihat perkembangan Return saham pada perusahaan Food and Baverages selama kurun waktu 4 tahun (2015-2018). Keadaan Return saham mengalami fluktuasi. Berdasarkan fenomena Return saham pada perusahaan Food and Baverages periode 2015-2018 dan adanya research gap pada hasil-hasil penelitian sebelumnya maka peneliti ingin meneliti apakah Return on Asset Return on Equity dan Earning Per Share berpengaruh dengan Return saham perusahaan Food and Baverages selama periode 2015-2018. 


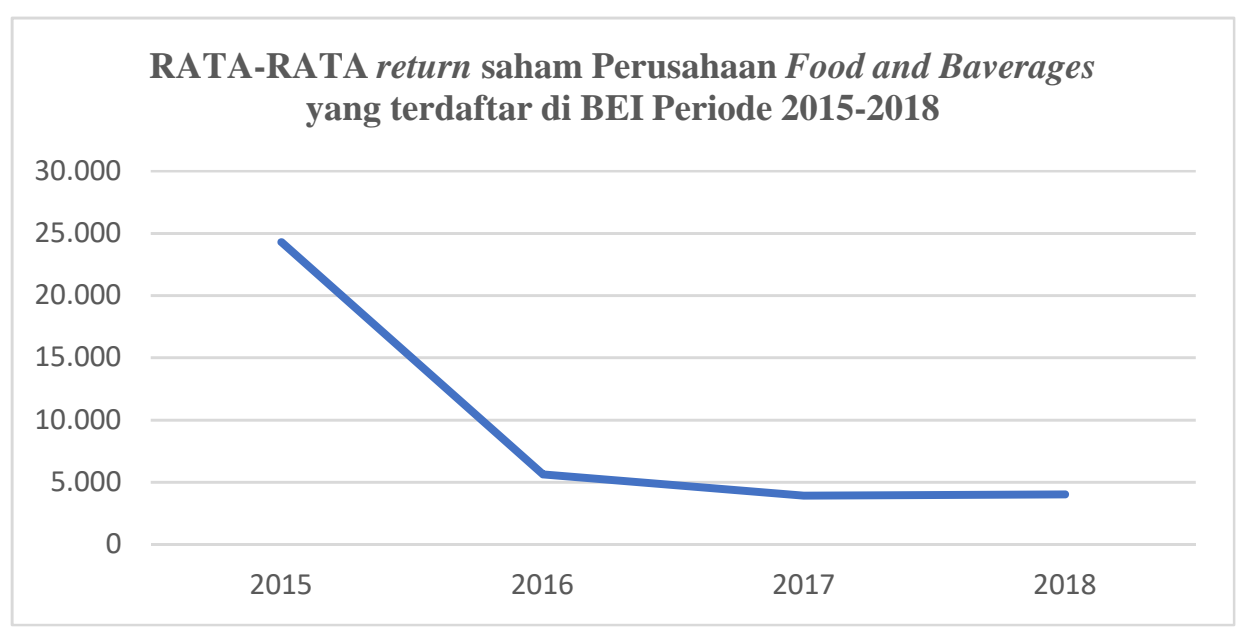

Gambar 1. Rata-rata return saham Perusahaan Food and Baverages yang terdaftar di BEI Periode 2015-2018

Sumber: Data diolah, 2019

Return on Equity adalah rasio profitabilitas yang menggambarkan kemampuan perusahaan dalam memberi keuntungan bagi pemegang saham biasa (pemilik modal) dengan menunjukkan laba bersih yang tersedia untuk modal pemegang saham yang telah digunakan perusahaan. ROE yang tinggi mencerminkan perusahaan berhasil menghasilkan keuntungan dari modal sendiri. Peningkatan ROE akan ikut mendongkrak nilai jual perusahaan yang berimbas pada harga saham, sehingga hal ini berkolerasi dengan peningkatan return saham.

Earning per Share adalah rasio antara laba bersih setelah pajak dengan jumlah lembar saham (Anwaar, 2016). Informasi EPS suatu perusahaan menunjukkan besarnya laba bersih perusahaan yang siap dibagikan kepada semua pemegang saham perusahaan. Apabila Earning per Share (EPS) semakin tinggi, maka semakin banyak investor yang mau membeli saham tersebut, sehingga menyebabkan harga saham akan tinggi (Stefano, 2015)

Penelitian yang dilakukan oleh Wahyuni (2017), hasil penelitiannya membuktikan bahwa EPS memilii hubungan positif dengan Return saham. Sedangkan hal yang berbeda di temukan dalam penelitian yang dilakukan oleh Arista (2012), hasil penelitiannya membuktikan bahwa Earning per Share memiliki hubungan negatif dan tidak signifikan dengan return saham.

Sektor Food and Baverages adalah perusahaan yang bergerak dalam bidang pengelolaan bahan baku menjadi produk jadi. Produk yang dihasilkan oleh Food and Baverages merupakan kebutuhan yang umumnya dikonsumsi oleh masyarakat. Jadi Sektor Food and Baverages ini memegang peran penting dalam kebutuhan sehari-hari masyarakat.

Berdasarkan latar belakang masalah yang telah diuraikan diatas, maka yang menjadi rumusan masalah dari penelitian ini adalah sebagai berikut: Apakah Return on Asset berpengaruh terhadap return saham?, Apakah Return on Equity berpengaruh terhadap return saham?, Apakah Earning Per Share berpengaruh terhadap return saham? 
Berdasarkan rumusan masalah diatas, maka yang menjadi tujuan dari penelitian ini adalah: Untuk mengetahui pengaruh Return on Asset terhadap return saham, Untuk mengetahui pengaruh Return on Equity terhadap return Saham , Untuk mengetahui pengaruh Earning Per Share terhadap return Saham

Teori yang mendasari penelitian ini adalah Signalling theory, teori yang membahas tentang naik turunnya harga di pasar, sehingga memberi pengaruh kepada keputusan investor. Signaling theory menekankan kepada informasi yang dikeluarkan perusahaan terhadap keputusan investasi di pihak luar perusahaan. (Abdul \& Awan, 2014).

Waktu informasi diumumkan dan semua pelaku pasar sudah menerima informasi tersebut, pelaku pasar terlebih dahulu menganalisis dan mengintepretasikan informasi tersebut sebagai sinyal bagus (good news) atau sebagai sinyal yang jelek ( ad news). Teori ini mengasumsikan manajer memiliki informasi yang lengkap tentang nilai perusahaan yang tidak diketahui oleh investor luar, dan manajer merupakan pihak yang selalu memaksimalkan insentif yang diharapkannya.

Undang-undang Pasar Modal No. 8 tahun 1995 tentang Pasar Modal di indonesia mendefinisikan Pasar Modal sebagai kegiatan yang bersangkutan dengan penawaran umum dan perdagangan efek, perusahaan publik yang berkaitan dengan efek yang diterbitkannya, serta lembaga dan profesi yang berkaitan dengan efek. Efek merupakan istilah buku yang digunakan undang-undang untuk menyatakan surat utang dan sekuritas. Pasar Modal menyediakan layanan yang menjembatani hubungan antara pemilik modal dalam hal ini disebut sebagai investor dengan meminjamkan dana kepada pihak yang membutuhkan modal, dalam hal ini, disebut sebagai emiten (perusahaan go public).

Pasar Modal menyediakan layanan yang menjembatani hubungan antara pemilik modal dalam hal ini disebut sebagai investor dengan meminjamkan dana kepada pihak yang membutuhkan modal, dalam hal ini, disebut sebagai emiten (perusahaan go public). Seperti aktivitas pasar pada umumnya, selain melibatkan penjual dan pembeli, barang dan jasa tertentu diperdagangkan. Di pasar modal, yang diperdagangkan adalah surat berharga.

Return saham merupakan hasil yang diperoleh dari suatu investasi dari dana yang sudah diinvestasikan yang dapat dinikmati oleh investor. Investor benar-benar harus menyadari bahwa disamping akan memperoleh keuntungan tidak menutup kemungkinan mereka akan mengalami kerugian. Keuntungan atau kerugian yang dialami investor sangat dipengaruhi oleh kemampuan seorang investor dalam menganalisis keadaan harga saham. Return dapat berupa return realisasi yaitu return yang telah terjadi, dithitung berdasarkan data hsitoris yang digunakan untuk mengukur kinerja perusahaan (Wijesundera et al. , 2016)

return historis ini berguna sebagai dasar penentuan return ekspektasi dan risiko di masa datang. return eskpektasi merupakan return yang belum terjadi tetapi yang diharapkan di masa yang mendatang yang bersifat tidak pasti. Oleh karena itu investor dihadapkan pada ketidakpastian antara return yang diharapkan dengan resiko yang diterima. Konsep Return adalah semakin tinggi tingkat return yang diharapkan maka semakin tinggi pula risiko yang akan diterima dan semakin rendah tingkat return yang diharapkan maka semakin rendah juga risiko yang diterima, 
Analisis fundamental adalah metode analisis yang didasarkan pada fundamental ekonomi suatu perusahaan. Teknik ini menitikberatkan pada rasio finansial dan kejadian-kejadian yang secara langsung maupun tidak langsung mempengaruhi kinerja keuangan perusahaan. Analisis fundamental berkaitan dengan penilaian kinerja perusahaan, tentang efektifitas dan efisiensi perusahaan dalam mencapai sasarannya.

Analisis fundamental berkaitan dengan penilaian kinerja perusahaan, tentang efektifitas dan efisiensi perusahaan dalam mencapai sasarannya. Analisis fundamental selalu memulai penilaian harga saham dengan melihat kepada pembelajaran atas laba historis dan pengujian atas laporan keuangan suatu perusahaan. Ide dasar pendekatan ini adalah bahwa harga saham akan dipengaruhi oleh kinerja perusahaan.

Rasio merupakan alat perbandingan jumlah, dimana suatu jumlah dibandingkan dengan jumlah lainnya, kemudian dilihat perbandingannya dengan harapan nantinya akan ditemukan jawaban yang selanjutnya itu ditemukan bahan kajian untuk dianalisis dan diputuskan. Pentingnya rasio keuangan dalam penilaian prestasi perusahaan bagi masyarakat, sangat berpengaruh terhadap kinerja keuangan suatu perusahaan. Karena rasio merupakan salah satu cara dimana seorang calon investor akan menilai kinerja keuangan melalui rasio-rasio keuangan sebelum melakukan investasi atau melakukan aktivitas pendanaan terhadap suatu perusahaan. Dalam melakukan penilaian terhadap kinerja keuangan perusahaan ada lima jenis analisis rasio yang paling sering digunakan, yaitu: Rasio likuiditas, Rasio aktivitas, Rasio solvabilitas, Rasio profitabilitas, Rasio pasar. Rasio profitabilitas ini mengukur kemampuan perusahaan menghasilkan keuntungan (profitabilitas) pada tingkat penjualan, asset, dan modal saham tertentu. Rasio ini terdiri atas Return on Asset dan Return on Equity.

Return on Asset (ROA) adalah rasio profitabilitas yang menunjukan kemampuan perusahaan untuk menghasilkan laba dari aktiva yang dipergunakan. Kinerja perusahaan jika di katakan semakin baik, jika menghasilkan ROA yang tinggi dan menunjukkan laju peningkatan dari waktu ke waktu akan menunjukkan kinerja perusahaan semakin baik, oleh karena itu harga saham akan meningkat yang menyebabkan tingkat return semakin besar, sehingga ROA dikatakan mempunyai pengaruh terhadap return saham.

Rasio keuangan perusahaan yang berhubungan dengan aspek earning atau profitabilitas. ROA berfungsi untuk mengukur efektivitas perusahaan dalam menghasilkan laba dengan memanfaatkan aktiva yang dimilikinya. Semakin besar ROA yang dimiliki suatu perusahaan maka semakin efisiensi pengguna aktiva sehingga akan memperbesar laba. Laba yang besar akan menarik investor karena perusahaan memiliki tingkat pengembalian yang semakin tinggi.

Return on Equity adalah rasio profitabilitas yang menggambarkan kemampuan perusahaan dalam memberi keuntungan bagi pemegang saham biasa (pemilik modal) dengan menunjukkan laba bersih yang tersedia untuk modal pemegang saham yang telah digunakan perusahaan. ROE yang tinggi mencerminkan perusahaan berhasil menghasilkan keuntungan dari modal sendiri. Peningkatan ROE akan ikut mendongkrang nilai jual perusahaan yang berimbas pada harga saham, Sehingga hal ini berkolerasi dengan peningkatan Return saham. 
Arta (2013) menyatakan semakin tinggi ROE maka semakin besar laba bersih yang diperoleh. Pembagian dividen kepada para pemegang saham tentu akan semakin besar sehingga terjadi kenaikkan Return saham. Apabila ROE rendah, maka mencerminkan perolehan laba bersih perusahaan yang rendah pula. Ini berakibat kepada saham perusahaan yang kurang diminati investor yang sebagai akibat pembagian dividen yang rendah. Sehingga minat investor pada saham tersebut berkurang sehingga otomatis mempengaruhi return saham. Keadaan ini berpengaruh terhadap penurunan Return saham.

Rasio pasar mengukur harga pasar relatif terhadap nilai buku. Sudut pandang rasio ini lebih banyak berdasar pada sudut investor (atau calon investor) meskipun pihak manajemen juga berkepentingan terhadap rasio-rasio ini. Rasio yang digunakan yaitu Earning Per Share. Informasi EPS suatu perusahaan menunjukkan besarnya laba bersih perusahaan yang siap dibagikan kepada semua pemegang saham perusahaan. Apabila EPS semakin tinggi, maka semakin banyak investor yang mau membeli saham tersebut, sehingga menyebabkan harga saham akan tinggi

ROA memiliki hubungan positif terhadap Return saham. Hasil penelitian Khalil (2016) menunjukkan bahwa ROA memiliki pengaruh positif dan signifikan terhadap Return saham. Temuan ini mengindikasikan bahwa semakin tinggi kemampuan perusahaan menghasilkan pendapatan, mengindikasikan bahwa semakin efisien perputaran aset perusahaan, yang berdampak secara langsung terhadap peningkatan nilai perusahaan. Hasil penelitian ini sejalan dengan penelitian yang dilakukan oleh Maringka et al. (2016), yaitu semakin tinggi ROA maka kinerja perusahaan semakin baik. Penelitian yang dilakukan Ika \& Listiorini (2017) menunjukkan bahwa ROA memiliki pengaruh positif dan signifikan terhadap Return saham. Hal ini mengidentifikasikan bahwa nilai perusahaan ditentukan oleh earning power dari aktiva perusahaan. Hasil yang positif menunjukkan bahwa semakin tinggi earning power maka akan semakin tinggi pula tingkat efisiensi perputaran aktiva dan semakin tinggi pula profit margin yang diperoleh oleh perusahaan, yang akan berdampak pada peningkatan nilai perusahaan maka perusahaan akan semakin diminati oleh para investor.

Return on Assets (ROA) perusahaan yang mengalami ketidakstabilan dan perbandingan laba perusahaan yang dihasilkan lebih kecil dibandingkan total asetnya menunjukkan bahwa perusahaan belum mampu mengelola asetnya secara efektif (Wahyuati \& Septiana, 2016). Hal tersebut menggambarkan perusahaan dengan ROA yang meningkat akan berpengaruh terhadap Return saham. Penelitian yang dilakukan Erari (2014) menghasilkan ROA berpengaruh positif terhadap Return saham. Penelitian Gunadi \& Kesuma (2015) juga menghasilkan ROA berpengaruh positif terhadap Return saham. Terjadinya peningkatan harga saham berakibat pula pada peningkatan Return saham perusahaan yang diterima pemegang saham. Pernyataan tersebut didukung oleh hasil penelitian yang dilakukan oleh Anistia et al. (2016), Rahyuda \& Puspitadewi (2016), Kabajeh et al. (2012) serta Utami (2014) bahwa ROA memiliki hubungan yang positif terhadap Return saham. Mengacu kepada deskripsi di atas, maka hipotesis yang akan diuji adalah:

$\mathrm{H}_{1}$ : Return on Assets (ROA) berpengaruh positif terhadap Return saham 
Return on Equity (ROE) mengukur berapa banyak keuntungan yang dihasilkan oleh perusahaan dibandingkan dengan modal sendiri. Menurut penelitian yang dilakukan Nalurita (2017) yang menemukan bahwa ROE memiliki pengaruh yang positif dan signifikan terhadap Return saham. Hasil penelitian Nasiri et al. (2016), Haque, 2013, Jabbari \& Fathi (2014) menemukan bahwa Return on Equity berpengaruh positif terhadap Return saham. Hal ini berarti semakin tinggi Return on Equity (ROE) suatu perusahaan, maka semakin tinggi pula Return saham yang dihasilkan. Berdasarkan temuan-temuan tersebut, maka hipotesis penelitian ini adalah:

$\mathrm{H}_{2}$ : Return on Equity (ROE) berpengaruh positif terhadap Return saham

Earning Per Share (EPS) adalah tingkat keuntungan bersih yang diperoleh investor per lembar saham yang dimilikinya semakin tinggi nilai EPS berarti semakin tinggi tingkat keuntungan per lembar saham yang dimiliki investor (Aisah \& Mandala, 2016). Hal ini dikuatkan dengan bukti empiris yang dilakukan oleh Wahyuni (2017) menyatakan bahwa EPS berpengaruh positif terhadap Return saham. Berdasarkan temuan-temuan tersebut, maka hipotesis penelitian ini adalah: $\mathrm{H}_{3}$ : Earning per share (EPS) berpengaruh positif terhadap Return saham

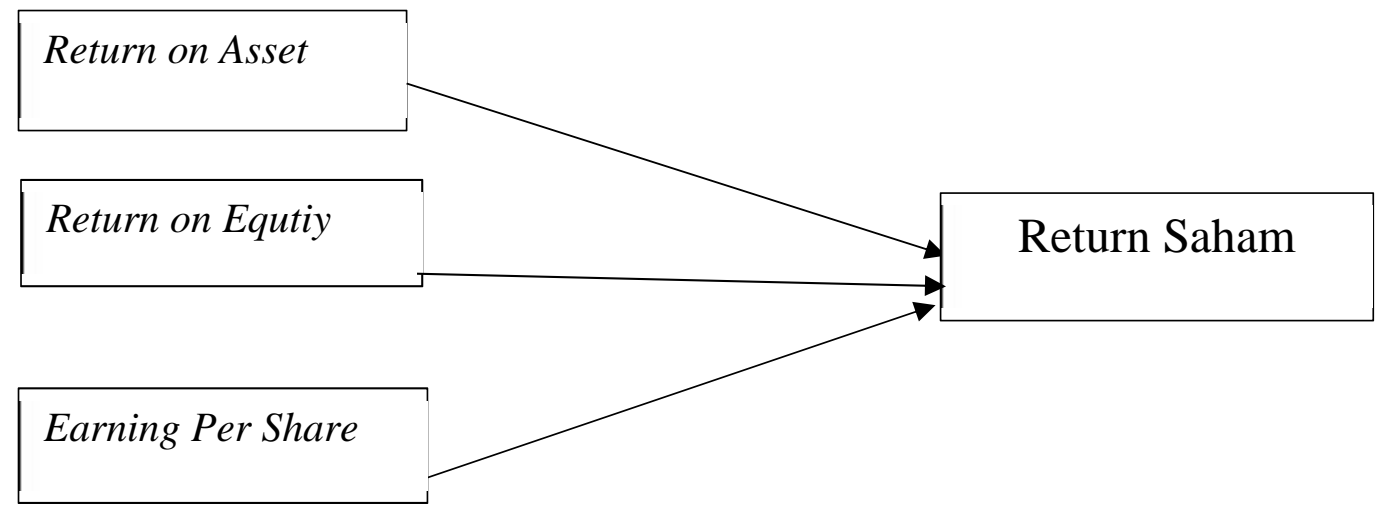

\section{Gambar 2. Kerangka Konseptual}

\section{METODE PENELITIAN}

Pendekatan yang digunakan dalam penelitian ini adalah berbentuk asosiatif. Penelitian ini dilakukan dengan melakukan pengambilan data pada perusahaan yang sahamnya terdaftar di Bursa Efek Indonesia periode 2015-2018 dengan mengakses website resmi Bursa Efek Indonesia, www.idx.co.id. Objek pada penelitian ini adalah Return Saham yang dipengaruhi oleh Return on Asset (ROA), Return on Equity (ROE), dan Earning Per Share (EPS). Variabel terikat dalam penelitian ini adalah Return Saham (Y). Variabel bebas (Independent): Variabel bebas dalam penelitian ini adalah Return on Asset $\left(\mathrm{X}_{1}\right)$, Return on Equity $\left(\mathrm{X}_{2}\right)$, Earning Per Share $\left(\mathrm{X}_{3}\right)$

Return on Asset (ROA) adalah rasio yang menunjukkan seberapa besar kontribusi asset dalam menciptakan laba bersih. Return on Asset dapat diukur dengan cara membandingkan laba bersih dengan total aktiva dari laporan keuangan perusahaan Food and Baverages di BEI tahun 2015-2018 dalam bentuk persentase. 
ROA $=\frac{\text { Laba bersih }}{\text { Total aktiva }} \times 100 \%$

Return on Equity ( $R O E$ ) adalah kemampuan perusahaan dalam menghasilkan keuntungan dengan modal sendiri yang dimiliki. Return on Equity dapat diukur dengan cara membandingkan laba bersih dengan total modal sendiri dari laporan keuangan perusahaan Food and Baverages di BEI tahun 2015-2018 dalam bentuk persentase.Rumus yang digunakan untuk menghitung besarnya ROE

$\mathrm{ROE}=$ Laba Bersih / Total modal sendiri $\mathrm{x} 100 \%$

Arista (2012) menyatakan bahwa Earning Per Share (EPS) merupakan pendapatan yang akan diterima oleh pemegang saham untuk setiap saham yang dimiliki atas keikutsertaan dalam perusahaan. Earning Per Share dapat diukur dengan cara membandingkan laba bersih dengan jumlah saham biasa beredar dari laporan keuangan perusahaan Food and Baverages di BEI periode 2015-2018.

EPS = Laba bersih / jumlah saham biasa beredar

Return saham merupakan selisih antara harga sahan tahun sekarang dengan harga saham tahun lalu dibagi dengan harga saham periode lalu yang dinyatakan dalam persentase pada perusahaan yang termasuk ke dalam sektor Food and Baverages periode 2015 - 2018 di Bursa Efek Indonesia. Rumus untuk mencari Return saham (Duy \& Huu Phuoc, 2016):

Return saham $=\frac{P_{\mathrm{L}}-\mathrm{P}_{\mathrm{t}-1}}{P_{\mathrm{t}-1}} \times 100 \%$

Keterangan:

$\mathrm{P}_{\mathrm{t}} \quad=$ Harga saham perusahaan pada periode sekarang $(\mathrm{t})$

$\mathrm{P}_{\mathrm{t}-1} \quad=$ Harga saham perusahaan pada periode lalu $(\mathrm{t}-1)$

Jenis data yang digunakan dalam penelitian ini adalah data kuantitatif. Data kuantitatif yang digunakan adalah Return on Asset, Return on Equity, dan Earning Per Share dan Return saham perusahaan Foood and Baverages di Bursa Efek Indonesia (BEI) periode 2015- 2018. Sumber data yang digunakan dalam penelitian ini adalah data sekunder yang diperoleh dari situs www.idx.co.id. Data Return on Asset, Return on Equity, dan Earning Per Share perusahaan Food and Baverages di Bursa Efek Indonesia.

Populasi dalam penelitian ini, yaitu seluruh perusahaan sector Food and Baverages di Bursa Efek Indonesia (BEI) periode 2015- 2018 yang berjumlah 13 perusahaan. Metode penentuan sampel yang digunakan dalam penelitian ini adalah sampling jenuh. Teknik ini dipilih karena jumlah populasi yang relatif kecil, yaitu sejumlah 15 perusahaan. Namun dua diantara perusahaan tersebut laporan keuangannya kurang lengkap, sehingga total sampel yang diperoleh sebanyak 13 perusahaan pada subsektor Food and Baverages di BEI tahun 2015-2018. Metode pengumpulan data menggunakan metode observasi nonparticipant.

\section{HASIL DAN PEMBAHASAN}

Penelitian ini menggunakan 13 perusahaan sebagai sampel penelitian yang didapatkan dari penelitian sebelumnya. Data yang digunakan dalam penelitian ini diperoleh dari website resmi Bursa Efek Indonesia (www.idx.com) berupa laporan tahunan dan laporan keuangan perusahaan pada periode 2015 sampai dengan 2018. 
Return on Assets (ROA) memiliki nilai minimal -0,204. Nilai maksimal sebesar 140 dan rata - rata sebesar 14,2265 dengan standar deviasi sebesar 44,27042. Return on Equity (ROE) memiliki nilai minimal -14, 99. Nilai maksimal sebesar 124,15 dan rata - rata sebesar 16,6915 dengan standar deviasi sebesar 26,53047. Earning per share (EPS) memiliki nilai minimal -32,66. Nilai maksimal sebesar 1.364,15 dan rata - rata sebesar 209, 0719 dengan standar deviasi sebesar 247, 74144. Return Saham memiliki nilai minimal 129. Nilai maksimal sebesar 26.916 dan rata - rata sebesar 5.595,2115 dengan standar deviasi sebesar $6.223,18130$.

Tabel 1.

Analisis Statistik Deskriptif

\begin{tabular}{lrrrrr}
\hline & N & \multicolumn{1}{c}{ Minimum } & Maximum & \multicolumn{1}{c}{ Mean } & Std. Deviation \\
\hline ROA & 52 & -204.00 & 140.00 & 14.2265 & 44.27042 \\
ROE & 52 & -14.99 & 124.15 & 16.6915 & 26.53047 \\
EPS & 52 & -32.66 & 1364.15 & 209.0719 & 247.74144 \\
Return Saham & 52 & 129.00 & 26916.00 & 5595.2115 & 6223.18130 \\
Valid N (listwise) & 52 & & & & \\
\hline
\end{tabular}

Sumber: Data sekunder diolah, 2019

Nilai Kolmogorov Sminarnov (K-S) pada tabel 3 sebesar 0,131 dan nilai Asymp. Sig. (2-tailed) sebesar 0,069. Hasil tersebut mengindikasikan bahwa model persamaan regresi tersebut berdistribusi normal karena nilai Asymp. Sig. (2-tailed) lebih besar dari nilai alpha 0, $05(0,069>0,05)$. Berdasarkan hasil grafik $p$ - $p$ plot diperoleh bahwa data menyebar disekitar garis diagonal atau grafik histogramnya menunjukan pola distribusi normal, maka model regresi memenuhi asumsi normalitas.

Tabel 2.

Hasil Uji Normalitas

\begin{tabular}{llr} 
& & Unstandardized Residual \\
\hline $\mathrm{N}$ & & 52 \\
Normal Parameters & & \multicolumn{1}{c}{,b } \\
& Mean & .0000000 \\
& Std. & 3949.92150187 \\
Most Extreme Differences & Deviation & .131 \\
& Absolute & .131 \\
Test Statistic & Positive & -.114 \\
Asymp. Sig. (2-tailed) & Negative & .131 \\
\hline
\end{tabular}

Sumber: Data sekunder diolah, 2019

Nilai signifikansi dari variabel Return on Assets (ROA) sebesar 0,177, nilai signifikan dari variabel Return on Equity (ROE) sebesar 0,346 dan nilai signifikansi dari variabel Earning per share (EPS) sebesar 0,667. Nilai 
tersebut lebih besar dari 0,05 yang berarti tidak terdapat gejala heteroskedastisitas. Berdasarkan output scatterplot bahwa tidak ada pola yang jelas, serta titik-titik menyebar diatas dan dibawah angka 0 pada sumbu Y. Sehingga dapat disimpulkan bahwa tidak terjadi masalah heteroskedastisitas

Tabel 3.

Hasil Uji Heteroskedastisitas

\begin{tabular}{|c|c|c|c|c|c|c|}
\hline \multirow{2}{*}{\multicolumn{2}{|c|}{ Model }} & \multicolumn{2}{|c|}{$\begin{array}{l}\text { Unstandardized } \\
\text { Coefficients }\end{array}$} & \multirow{2}{*}{$\begin{array}{c}\begin{array}{c}\text { Standardized } \\
\text { Coefficients }\end{array} \\
\text { Beta } \\
\end{array}$} & \multirow[b]{2}{*}{$\mathbf{t}$} & \multirow[b]{2}{*}{ Sig. } \\
\hline & & B & Std. Error & & & \\
\hline \multirow[t]{4}{*}{1} & (Constant) & 2247.096 & 551.583 & & 4.074 & .000 \\
\hline & ROA & 13.685 & 9.991 & .203 & 1.370 & .177 \\
\hline & ROE & 17.445 & 18.334 & .155 & .951 & .346 \\
\hline & EPS & -.849 & 1.961 & -.070 & -.433 & .667 \\
\hline
\end{tabular}

Tabel 4.

Hasil Uji Multikolinieritas

\begin{tabular}{|c|c|c|c|}
\hline \multirow{2}{*}{\multicolumn{2}{|c|}{ Model }} & \multicolumn{2}{|c|}{ Collinearity Statistics } \\
\hline & & Tolerance & VIF \\
\hline \multirow[t]{3}{*}{1} & ROA & .886 & 1.128 \\
\hline & ROE & .733 & 1.364 \\
\hline & EPS & .734 & 1.362 \\
\hline
\end{tabular}

Sumber: Data sekunder diolah, 2019

Nilai tolerance dan VIF dari variabel Return on Assets (ROA) berturutturut 0,886 dan 1,128, nilai tolerance dan VIF dari variabel Return on Equity (ROE) berturut-turut 0,733 dan 1,364 dan nilai tolerance dan VIF dari variabel Earning per share (EPS) berturut-turut 0,734 dan 1,362 semua menunjukkan nilai tolerance untuk setiap variabel lebih besar dari 0,1 dan nilai VIF lebih kecil dari 10 yang berarti model persamaan regresi bebas dari multikolinearitas.

Tabel 5.

Hasil Uji Autokorelasi

\begin{tabular}{|c|c|c|c|c|c|}
\hline & & & Model & $\mathbf{R}$ & R Square \\
\hline 1 & $.773^{\mathrm{a}}$ & .597 & .572 & 4071.48589 & 1.967 \\
\hline
\end{tabular}

Pada Tabel 5. dapat dilihat bahwa nilai nilai Durbin Watson (d-hitung) sebesar 1,967. Dengan signifikan sebesar 0,05 dan $\mathrm{N}=52$ dan jumlah variabel bebas $\mathrm{k}=3$, maka diperoleh nilai $\mathrm{du}=1,6769$ diperoleh nilai $\left(4-\mathrm{d}_{\mathrm{u}}\right)$ sebesar 4 $1,6769=2,3231$. Oleh karena nilai Durbin Watson (d-hitung) sebesar 1,967 berada diantara 1, 6769 dan 2, 3231 sehingga dapat disimpulkan bahwa tidak terjadi autokorelas. 
Berdasarkan hasil analisis regresi seperti yang disajikan pada Tabel 7, maka dapat dibuat persamaan struktural sebagai berikut:

$\mathrm{Y}=1559,297+31,812 \mathrm{X}_{1}+81,256 \mathrm{X}_{2}+10,652 \mathrm{X}_{3}$

Nilai konstanta sebesar 1559,297, artinya jika variabel Return on Assets (ROA), Return on Equity (ROE), dan Earning per share (EPS) bernilai 0 maka nilai Return Saham sebesar 29,234. Nilai koefisien variabel Return on Assets (ROA) $\left(\mathrm{X}_{1}\right)$ bernilai positif 31,812 , artinya apabila Return on Assets (ROA) ( $\left.\mathrm{X}_{1}\right)$ mengalami peningkatan satu satuan dengan asumsi variabel Return on Equity (ROE) dan Earning per share (EPS) dianggap tetap maka nilai Return Saham akan meningkat sebesar 31,812.

Tabel 6.

Hasil Analisis Regresi Linier Berganda

\begin{tabular}{|c|c|c|c|c|c|c|}
\hline \multirow[b]{2}{*}{ Model } & & \multicolumn{2}{|c|}{$\begin{array}{l}\text { Unstandardized } \\
\text { Coefficients }\end{array}$} & \multirow{2}{*}{$\begin{array}{c}\begin{array}{c}\text { Standardized } \\
\text { Coefficients }\end{array} \\
\text { Beta }\end{array}$} & \multirow[b]{2}{*}{$\mathbf{t}$} & \multirow[b]{2}{*}{ Sig. } \\
\hline & & B & $\begin{array}{l}\text { Std. } \\
\text { Error }\end{array}$ & & & \\
\hline \multirow[t]{4}{*}{1} & (Constant) & 1559.297 & 755.180 & & 2.065 & .044 \\
\hline & $\mathrm{ROA}$ & 31.812 & 13.678 & .226 & 2.326 & .024 \\
\hline & ROE & 81.256 & 25.102 & .346 & 3.237 & .002 \\
\hline & EPS & 10.652 & 2.685 & .424 & 3.967 & .000 \\
\hline$R$ Square & $: 0,597$ & & & & & \\
\hline Adjused $R$ Square & $: 0,572$ & & & & & \\
\hline Signifikansi F & $: 0,000$ & & & & & \\
\hline F hitung & $: 23,716$ & & & & & \\
\hline
\end{tabular}

Nilai koefisien variabel Return on Equity (ROE) $\left(\mathrm{X}_{2}\right)$ bernilai positif 81,256, artinya apabila Return on Equity (ROE) $\left(\mathrm{X}_{2}\right)$ mengalami peningkatan satu satuan dengan asumsi variabel Return on Assets (ROA) dan Earning per share (EPS) dianggap tetap maka Return Saham akan meningkat sebesar 81,256 .

Nilai koefisien variabel Earning per share (EPS) $\left(\mathrm{X}_{3}\right)$ bernilai positif 10,652, artinya apabila Earning per share (EPS) $\left(\mathrm{X}_{3}\right)$ mengalami peningkatan satu satuan dengan asumsi variabel Return on Assets (ROA) dan Return on Equity (ROE) dianggap tetap maka Return Saham akan meningkat sebesar 10,652.

Tabel 7.

Hasil Uji Kelayakan Model

\begin{tabular}{llrrrrr}
\hline Model & & Sum of Squares & df & Mean Square & \multicolumn{1}{c}{ F } & \multicolumn{1}{c}{ Sig. } \\
\hline 1 & Regression & 1179431385.255 & 3 & 393143795.085 & 23.716 & $.000^{\mathrm{b}}$ \\
& Residual & 795695873.419 & 48 & 16576997.363 & & \\
& Total & & & & & \\
& & 1975127258.673 & 51 & & &
\end{tabular}

Sumber: Data sekunder diolah, 2019 
Hasil uji signifikansi simultan (Uji $\mathrm{F}$ ) diperoleh nilai signifikansi $\mathrm{F}$ sebesar 0,000. Nilai Signifikansi $0,000<0,05$ mengindikasikan bahwa Return on Assets (ROA), Return on Equity (ROE), dan Earning per share (EPS) tepat sebagai model penentu Return saham sehingga model layak digunakan untuk memprediksi.

Hasil uji t Return on Assets (ROA) terhadap Return Saham diperoleh nilai signifikansi sebesar 0,024 dengan nilai koefisien beta 31,812 bernilai positif. Nilai Signifikansi $0,024<0,05$ mengindikasikan bahwa $\mathrm{H}_{1}$ diterima. Hasil ini mempunyai arti bahwa Return on Assets (ROA) berpengaruh positif terhadap Return saham pada perusahaan Food and Baverages di Bursa Efek Indonesia.

Hasil uji t Return on Equity (ROE) terhadap Return saham diperoleh nilai signifikansi sebesar 0,02 dengan nilai koefisien beta 81,256 bernilai negatif. Nilai Signifikansi 0,02> 0,05 mengindikasikan bahwa $\mathrm{H}_{1}$ diterima. Hasil ini mempunyai arti bahwa Return on equity (ROE) berpengaruh positif terhadap Return saham pada perusahaan Food and Baverages di Bursa Efek Indonesia.

Hasil uji t Earning per share (EPS) terhadap Return Saham diperoleh nilai signifikansi sebesar 0,000 dengan nilai koefisien beta 10,652 bernilai positif. Nilai Signifikansi $0,000<0,05$ mengindikasikan bahwa $\mathrm{H}_{1}$ diterima. Hasil ini mempunyai arti bahwa Earning per share (EPS) berpengaruh positif terhadap Return saham pada perusahaan Food and Baverages di Bursa Efek Indonesia.

Tabel 8.

Hasil Analisis Uji T

\begin{tabular}{|c|c|c|c|c|c|c|}
\hline \multirow[b]{2}{*}{ Model } & & \multicolumn{2}{|c|}{$\begin{array}{c}\text { Unstandardized } \\
\text { Coefficients }\end{array}$} & \multirow{2}{*}{$\begin{array}{c}\begin{array}{c}\text { Standardized } \\
\text { Coefficients }\end{array} \\
\text { Beta } \\
\end{array}$} & \multirow[b]{2}{*}{$\mathbf{t}$} & \multirow[b]{2}{*}{ Sig. } \\
\hline & & B & $\begin{array}{c}\text { Std. } \\
\text { Error }\end{array}$ & & & \\
\hline \multirow[t]{4}{*}{1} & (Constant) & 1559.297 & 755.180 & & 2.065 & .044 \\
\hline & ROA & 31.812 & 13.678 & .226 & 2.326 & .024 \\
\hline & ROE & 81.256 & 25.102 & .346 & 3.237 & .002 \\
\hline & EPS & 10.652 & 2.685 & .424 & 3.967 & .000 \\
\hline$R$ Square & $: 0,597$ & & & & & \\
\hline Adjused $R$ Square & $: 0,572$ & & & & & \\
\hline Signifikansi F & $: 0,000$ & & & & & \\
\hline F hitung & $: 23,716$ & & & & & \\
\hline
\end{tabular}

Pengaruh Return on Asset (ROA) terhadap Return sahamBerdasarkan Tabel 8. hasil uji t Return on Assets (ROA) terhadap Return Saham diperoleh nilai signifikansi sebesar 0,024 dengan nilai koefisien beta 31,812 bernilai positif. Nilai Signifikansi $0,024<0,05$ mengindikasikan bahwa $\mathrm{H}_{1}$ diterima. Hasil ini mempunyai arti bahwa Return on Assets (ROA) berpengaruh positif terhadap Return saham pada perusahaan Food and Baverages di Bursa Efek Indonesia.Pengaruh Return on Equity terhadap Return saham Berdasarkan Tabel 4.6 hasil uji t Return on Equity (ROE) terhadap Return saham diperoleh nilai signifikansi sebesar 0,02 dengan nilai koefisien beta 81,256 bernilai negatif. Nilai 
Signifikansi 0,02> 0,05 mengindikasikan bahwa $\mathrm{H}_{1}$ diterima. Hasil ini mempunyai arti bahwa Return on equity (ROE) berpengaruh positif terhadap Return saham pada perusahaan Food and Baverages di Bursa Efek Indonesia.

Pengaruh Earning per share (EPS) terhadap Return Saha Berdasarkan Tabel 8. hasil uji t Earning per share (EPS) terhadap Return Saham diperoleh nilai signifikansi sebesar 0,000 dengan nilai koefisien beta 10,652 bernilai positif. Nilai Signifikansi $0,000<0,05$ mengindikasikan bahwa $\mathrm{H}_{1}$ diterima. Hasil ini mempunyai arti bahwa Earning per share (EPS) berpengaruh positif terhadap Return saham pada perusahaan Food and Baverages di Bursa Efek Indonesia.

Tabel 9.

Hasil Analisis Koefisien Determinasi

\begin{tabular}{l|rrrr}
\hline Model & R & R Square & Adjusted R Square & $\begin{array}{c}\text { Std. Error of the } \\
\text { Estimate }\end{array}$ \\
\hline 1 & $.773^{\mathrm{a}}$ & .597 & .572 & 4071.48589 \\
a. Predictors: (Constant), EPS, ROA, ROE & & & \\
b. Dependent Variabel: Return Saham & & & \\
\hline Sumber: Data sekunder diolah, 2019 & &
\end{tabular}

Pengaruh variabel bebas terhadap variabel terikat yang ditunjukkan oleh nilai determinasi total (Adjused $R$ Square) sebesar 0,572 mempunyai arti bahwa sebesar 57,2\% variasi Return saham dipengaruhi oleh variasi Return on Assets (ROA), Return on Equity (ROE), dan Earning per share (EPS), sedangkan sisanya sebesar $42,8 \%$ dijelaskan oleh faktor lain yang tidak dimasukkan ke dalam model.

Penelitian ini menemukan bahwa Return on Asset berpengaruh positif dan signifikan terhadap Return saham. Hal ini menunjukkan bahwa semakin meningkat ROA maka dapat meningkatkan Return saham pada perusahaan Food and Baverages di Bursa Efek Indonesia. Dengan meningkatnya ROA akan dapat menarik investor untuk berinvestasi sehingga hal ini akan menaikkan harga saham. Sebaliknya jika ROA semakin menurun, maka return saham pada perusahaan Food and Baverages di Bursa Efek Indonesia akan semakin menurun pula.

Profitabilitas mencerminkan tingkat efektivitas manajemen suatu perusahaan yang dapat dilihat dari laba penjualan dan pendapatan investasi (Sutriani, 2014). Apabila manajemen menjalankan kegiatannya dengan efektif, laba dari penjualan dan pendapatan investasi akan meningkat. Semakin tinggi profitabilitas suatu perusahaan maka perusahaan tersebut memiliki tingkat efisiensi yang semakin tinggi pula. Profitabilitas yang tinggi dapat merupakan indikator kemampuan perusahaan dan secara tidak langsung dapat membangun prospek yang baik bagi perusahaan (Saputri \& Wijaya, 2018). Hal ini dapat meningkatkan kepercayaan investor, meningkatkan harga saham di pasaran, dan Return saham juga akan meningkat seiring dengan peningkatan harga saham. Profitabilitas diukur dengan rasio profitabilitas. 
ROA memiliki pengaruh positif terhadap Return saham, mendukung hasil penelitian Khalil (2016).Temuan ini mengindikasikan bahwa semakin tinggi kemampuan perusahaan menghasilkan pendapatan, mengindikasikan bahwa semakin efisien perputaran aset perusahaan, yang berdampak secara langsung terhadap peningkatan nilai perusahaan. Hasil penelitian ini sejalan juga dengan temuan penelitian yang dilakukan oleh Maringka et al. (2016), yaitu semakin tinggi ROA maka kinerja perusahaan semakin baik. Penelitian yang dilakukan Ika \& Listiorini (2017) menunjukkan bahwa ROA memiliki pengaruh positif dan signifikan terhadap Return saham. Hal ini mengidentifikasikan bahwa nilai perusahaan ditentukan oleh earning power dari aktiva perusahaan. Hasil yang positif menunjukkan bahwa semakin tinggi earning power maka akan semakin tinggi pula tingkat efisiensi perputaran aktiva dan semakin tinggi pula profit margin yang diperoleh oleh perusahaan, yang akan berdampak pada peningkatan nilai perusahaan maka perusahaan akan semakin diminati oleh para investor ROA perusahaan yang mengalami ketidakstabilan dan perbandingan laba perusahaan yang dihasilkan lebih kecil dibandingkan total assetnya menunjukkan bahwa perusahaan belum mampu mengelola asetnya secara efektif (Wahyuati \& Septiana, 2016). Hal tersebut menggambarkan perusahaan dengan ROA yang meningkat akan berpengaruh terhadap Return saham. Penelitian yang dilakukan Erari (2014) menghasilkan ROA berpengaruh positif terhadap Return saham.

Penelitian Gunadi \& Kesuma (2015) juga menghasilkan ROA berpengaruh positif terhadap Return saham. Terjadinya peningkatan harga saham berakibat pula pada peningkatan Return saham perusahaan yang diterima pemegang saham. Pernyataan tersebut didukung oleh hasil penelitian yang dilakukan oleh Anistia et al. (2016), Rahyuda \& Puspitadewi (2016), Kabajeh et al. (2012), serta Utami (2014) bahwa ROA memiliki pengaruh yang positif terhadap Return saham.

Penelitian ini menemukan Return on Equity berpengaruh positif dan signifikan terhadap return saham pada Perusahaan Food and Baverages di Bursa Efek Indonesia. Dengan kata lain nilai ROE yang tinggi akan dapat menarik investor untuk berinvestasi atau menanamkam modalnya, hal ini akan berpengaruh pada meningkatnya harga saham. Sebaliknya jika ROE semakin menurun maka investor tidak tertarik untuk berinvestasi sehingga returm saham pada Perusahaan Food and Baverages di Bursa Efek Indonesia akan semakin menurun.

Salah satu jenis rasio yang digunakan untuk mengukur tingkat keuntungan atau profitabilitas suatu perusahaan adalah ROE (Isaac et al., 2017). Rasio ini mengukur berapa banyak keuntungan yang dihasilkan oleh perusahaan dibandingkan dengan modal sendiri. Menurut penelitian yang dilakukan oleh Wahyuni (2017) hasil penelitiannya menunjukkan bahwa ROE memiliki hubungan positif terhadap Return saham. Hasil penelitian yang sama dilakukan oleh Nalurita (2017) yang menemukan bahwa ROE memiliki pengaruh yang positif dan signifikan terhadap Return saham. Hasil penelitian Nasiri et al. (2016), Haque (2013), dan Jabbari \& Fathi (2014) menemukan bahwa ROE berpengaruh positif terhadap Return saham. Hal ini berarti semakin tinggi ROE suatu perusahaan, maka semakin tinggi pula Return saham yang dihasilkan.

Penelitian ini menunjukkan bahwa Earning Per Share berpengaruh positif dan signifikan terhadap Return saham pada Perusahaan Food and Baverages di 
Bursa Efek Indonesia. Dengan kata lain semakin meningkat EPS maka akan dapat menarik investor untuk berinvestasi sehingga harga saham naik. Hal ini akan meningkatkan Return Saham pada Perusahaan Food and Baverages di Bursa Efek Indonesia. Sebaliknya jika EPS semakin menurun maka Return Saham pada Perusahaan Food and Baverages di Bursa Efek Indonesia juga akan semakin menurun.

EPS adalah tingkat keuntungan bersih yang diperoleh investor per lembar saham yang dimilikinya. Semakin tinggi nilai EPS berarti semakin tinggi tingkat keuntungan per lembar saham yang dimiliki investor. Hal ini dikuatkan dengan bukti empiris yang dilakukan oleh Wahyuni (2017) yang menemukan bahwa EPS berpengaruh positif terhadap Return saham.

\section{SIMPULAN}

Berdasarkan hasil analisis penelitian dan hasil pembahasan pada bab sebelumnya maka simpulan dari penelitian ini Return on Assets berpengaruh positif terhadap Return saham. Hal ini berarti semakin meningkat ROA maka dapat meningkatkan Return saham pada perusahaan Food and Baverages di Bursa Efek Indonesia. Nilai Return on Assets (ROA) yang tinggi akan dapat menarik investor untuk berinvestasi sehingga menyebabkan meningkatnya harga saham. Sebaliknya jika Return on Assets (ROA) menurun, dapat menurunkan returm saham pada perusahaan Food and Baverages di Bursa Efek Indonesia. Return on Equity berpengaruh positif dan signifikan terhadap Return saham. Hal ini berarti semakin meningkat ROE akan semakin meningkatkan Return saham pada Perusahaan Food and Baverages di Bursa Efek Indonesia. Dengan kata lain meningkatnya nilai Return on Equity (ROE) akan dapat menarik investor untuk berinvestasi yang berpengaruh dalam meningkatnya harga saham. Sebaliknya jika Return on equity (ROE) menurun, dapat menurunkan returm saham pada Perusahaan Food and Baverages di Bursa Efek Indonesia.

Earning Per Share berpengaruh positif dan signifikan terhadap Return saham pada Perusahaan Food and Baverages di Bursa Efek Indonesia. Hal ini berarti semakin meningkat EPS akan semakin meningkatkan Return Saham pada Perusahaan Food and Baverages di Bursa Efek Indonesia. Dengan kata lain semakin tinggi nilai Earning per Share (EPS) semakin banyak menarik investor untuk menanamkan modalnya sehingga dapat meningkatkan harga saham. sebaliknya jika Earning per share (EPS) menurun, dapat menurunkan Return Saham pada Perusahaan Food and Baverages di Bursa Efek Indonesia. Berdasarkan simpulan tersebut maka saran dari penelitian ini adalah Bagi perusahaan, hasil penelitian ini dapat digunakan sebagai bahan informasi pengambilan keputusan keuangan yaitu meningkatkan profitabilitas dalam menentukan harga saham atau Return saham.

Bagi Peneliti selanjutnya, penelitian ini memiliki keterbatasan hanya pada variabel Return on Assets, Return on equity, dan Earning per share sebagai determinan Return saham, maka penelitian selanjutnya bisa menggunakan keputusan keuangan seperti investasi dan pendanaan 


\section{REFERENSI}

A. Sorongan, F. (2016). Factors Affecting the Return Stock Company in Indonesia Stock Exchange (IDX) LQ45 in Years 2012-2015. The Winners, 17(1), 37. https://doi.org/10.21512/tw.v17i1.1808

Abdul, P., \& Awan, G. (2014). The Effect Of Economic Value Added On Stock Return: Evidence From Selected Companies Of Karachi Stock Exchange. 5(23), 140-153.

Aisah, A., \& Mandala, K. (2016). Pengaruh Return on Equity, Earning Per Share, Firm Size Dan Operating Cash Flow Terhadap Return Saham. E-Jurnal Manajemen Universitas Udayana, 5(11), 6907-6936.

Alun, T., \& Sakti, A. (2007). Pengaruh Return on Asset Dan Debt To Equity Ratio Terhadap Return Saham Pada Perusahaan Yang Terdaftar Di Bursa Efek.

Angela, L., Komala, P., \& Nugroho, I. (2013). The Effects of Profitability Ratio, Liquidity, and Debt towards Investment Return. Journal of Business and Economics, 4(11), 1176-1186. Retrieved from http://www.academicstar.us

Anwaar, M. (2016). Global Journal of Management and Business Research: D Accounting and Auditing Volume. Impact of F irms' Performance on Stock Returns (Evidence From Listed Companies of Fste100 Index London, Uk), $16(1)$.

Arista, D. (2012). Analisa Faktor - Faktor Yang Mempengaruhi Return Saham (Kasus pada Perusahaan Manufaktur yang Go Public di BEI Periode Tahun 2005 - 2009). Jurnal Ilmu Manajemen Dan Akuntansi Terapan, 3, 1-15.

Darmadji, H. M. F. (2006). Pasar Modal di Indonesia Pendekatan Tanya Jawab. Jakarta:Salemba Empat, (101), 1-6.

Duy, N. T., \& Huu Phuoc, N. P. (2016). The Relationship between Firm Sizes and Stock Returns of Service Sector in Ho Chi Minh City Stock Exchange. Review of European Studies, 8(4), 210. https://doi.org/10.5539/res.v8n4p210

Erari, A. (2014). Analisis Pengaruh Current Ratio, Debt To Equity Ratio, dan Return On Asset Terhadap Return Saham Pada Perusahaan Pertambangan di Bursa Efek Indonesia. Jurnal Manajemen Bisnis Universitas Muhammadiyah Yogyakarta, 5(2), 174-191.

Farkhan, \& Ika. (2013). Pengaruh Rasio Keuangan Terhadap Return Saham Perusahaan Manufaktur Di Bursa Efek Indonesia. Jurnal Unimus, 9(1), 1-18. Retrieved from http://jurnal.unimus.ac.id

Gunadi, G., \& Kesuma, K. (2015). Pengaruh Roa, Der, Eps Terhadap Return Saham Perusahaan Food and Beverage Bei. E-Jurnal Manajemen Universitas Udayana, 4(6), 1636-1647. 
Harahap, S. S. (2007). Analisis Krirtis Atas Laporan Keuangan. Jakarta: PT.Raja Grasindo Persada., 2006.

Harjito, D. A., \& Rangga, D. A. N. (2009). Analisis Pengaruh Kinerja Keuangan dan Return Saham di Bursa Efek Indonesia. 7, 13-21.

Husnan, S. (2009). Dasar-Dasar Teori Porotofolio dan Analisis Sekuritas. Edisi Ke 4. Yogyakarta: UPP STIM YKPN., (101), 1-6.

Ika, D., \& Listiorini. (2017). Analisis Faktor-Faktor Fundamental Yang Mempengaruhi Return Saham Perusahaan Yang Terdaftar Dalam Indeks LQ 45 Di Bursa Efek Indonesia Periode Tahun 2013-2015. Jurnal Akuntansi Dan Bisnis, 3(1), 1-14.

Indah Wahyuni, S. (n.d.), the Effect of Earning Per Share (Eps), Book Value ( Bv ), Return on Assets ( Roa ), and Return on Equity ( Roe ) To the.

Iqbal Khan, K. (2012). Effect of Dividends on Stock Prices- A Case of Chemical and Pharmaceutical Industry of Pakistan. Management, 2(5), 141-148. https://doi.org/10.5923/j.mm.20120205.02

Isaac, M., Willy, M., \& Anthony, W. (2017). The Influence of Credit Risk on Stock Returns. International Journal of Scientific and Research Publications, 7(5), 575-584.

Jabbari, E., \& Fathi, Z. (2014). Prediction of Stock Returns Using Financial Ratios Based on Historical Cost , Compared With Adjusted Prices ( Accounting for Inflation ) With Neural. Indian Journal of Fundamental and Applied Life Sciences, 4(2003), 1064-1078.

Kabajeh, M. A. M., Al-Nu'aimat, S. M. A., \& Dahmash, F. N. (2012). The Relationship Between ROA, ROE and ROI Ratios with Jordanian Insurance Public Companies Market Share Prices. International Journal of Humanities and Social Science, 2(11), 115-120.

Kasmir. (2010). Pengantar Manajemen Keuangan Edisi Kedua. . . Jakarta: Prenadamedia Group. https://doi.org/10.1080/02673843.2013.847850

Khalil, M., Sciences, M., \& April, P. (2016). the Effect of Corporate Cash Holdings on Stock Returns I . Introduction. 6(6). https://doi.org/10.4172/22235833.1000262

Kohansal, M. R., Dadrasmoghaddam, A., Karmozdi, K. M., \& Mohseni, A. (2013). Relationship between Financial Ratios and Stock Prices for the Food Industry Firms in Stock Exchange of Iran. WAP Journal, 3(101), 512-521.

Kurniawan, A. (2011). Pengaruh Kinerja Keuangan Terhadap Return Saham Pada Perusahaan Manufaktur yang Terdaftar di Bursa efek Indonesia Periode 2008-2010. 
Makeni, E. N. (2018), the Effect of Foreign Direct Investments on Stock Market Returns At the Nairobi Securities Exchange By a Research Project Submitted in Partial Fulfillment of the Requirements for the Award of the Degree of Master of Science in Finance, School of Business. (December).

Malintan, R. (2010). Pengaruh Current Ratio (CR), Debt To Equity Ratio (DER), Price Earning Ratio (PER), dan Return On Asset (ROA) Terhadap Return Saham Perusahaan Pertambangan Yang Terdafta di Bursa Efek Indonesia Tahun 2005-2010. (45), 39. Retrieved from https://www.nber.org/papers/w15827.pdf

Maringka, T. S., Moeljadi, P., Djazuli, A., \& Ratnawati, K. (2016). Leverage , Free Cash Flow, and Interest Rates Influence of Stock Return and Financial Performance as Intervening Variables ( Study on Manufacturing Industry Listed in Indonesia Stock Exchange ). International Journal of Business and Manageemnt Invention, 5(2), 28-30.

Nalurita, F. (2017). the Effect of Profitability Ratio, Solvability Ratio, Market Ratio on Stock Return. Business and Entrepreneurial Review, 15(1), 73. https://doi.org/10.25105/ber.v15i1.2080

Nasiri, M. M., Mir, M., \& Samani, A. R. (2016). The effect of shareholders' combination on risk taking of the companies listed in Tehran Stock Exchange. International Journal of Business Continuity and Risk Management, 6(3), 209. https://doi.org/10.1504/ijbcrm.2016.079009

Nesa Anisa. (2015). Analisis faktor-faktor yang mempengaruhi Return saham (Studi Kasus Pada Perusahaan Sub Sector Automotive And Components yang terdaftar di BUrsa Efek Indonesia Periode 2010-2014). Perbanas Review, 1 NOMOR 1(November), 72-86. https://doi.org/10.1016/j.bbr.2010.05.009

Nurhakim Anistia, Irni, Y., \& Iradianty, A. (2016). the Effect of Profitability and Inflation on Stock Return At Pharmaceutical Industries At Bei in the Period of 2011-2014. Asia PACIFIC JOURNAL oF Advanced Business and Social Studies, 2(2), 202-210.

Olowoniyi, A. O., \& Ojenike, J. O. (2012). Determinants of Stock Return of Nigerian-Listed Firms. Journal of Emerging Trends in Economics and Management Sciences, 3(4), 389-392.

Pouraghajan, A., Emamgholipour, M., Niazi, F., \& Samakosh, A. (2012). Information Content of Earnings and Operating Cash Flows: Evidence from the Tehran Stock Exchange. International Journal of Economics and Finance, 4(7), 41-51. https://doi.org/10.5539/ijef.v4n7p41

Putri, A. A. B., \& Sampurno, R. D. (2012). Analisis pengaruh ROA, EPS, NPM, DER dan PBV terhadap return saham (Studi kasus pada industri Real Estate and Property yang terdaftar di Bursa Efek Indonesia periode 2007-2009). Diponegoro Business Review, 1, 1-11. 
Rahyuda, H., \& Puspitadewi, C. I. I. (2016). Pengaruh ROA, PER dan EVA Terhadap Return Saham Pada perusahaan FOOD AND BAVERAGES Di BEI. E-Jurnal Akuntansi Universitas Udayana, 5(3), 1429-1456.

Rumokoy, F., \& Tamunu, S. C. (2015). The Influence of Fundamental Factors on Stock Return (Case Study: Company Listed in Lq45 2011-2014). Jurnal Riset Ekonomi, Manajemen, Bisnis Dan Akuntansi, 3(4).

Saeed, G. (n.d.). The Impact of Firm Growth on Stock Returns of Nonfinancial Firms Listed on Egyptian Stock Exchange Literature Review: 1 . Firm growth. 1-17.

Saputri, A. E., \& Wijaya, I. (2018). Return Saham Ditinjau dari Rasio Keuangan , Inflasi, Suku. Insan Akuntan, 3(1), 11-20.

Saqafi, Vahid Hamidreza vakilifard, P. . F. (2012). I Nterdisciplinary J Ournal O F $C$ Ontemporary $R$ Esearch I $N B$ Usiness the Effect of Variables of the Fundamental Techniques on. 808-814.

Simu, B. Y. S. N. (2013). Current Ratio, Debt To Equity Ratio, Return On Assets. $4,1-15$.

Sri Zuliarni. (2012). Pengaruh Kinerja Keuangan Terhadap Harga Saham Pada Perusahaan Mining and Mining Service Di Bursa Efek Indonesia (BEI). Jurnal Aplikasi Bisnis, 3(1), 36-48.

Stefano, K. (2015). The Impact of Financial Ratio toward Stock Return of Property Industry in Indonesia. IBuss Management, 3(2), 222-231.

Sutriani, A. (2014). Pengaruh Profitabilitas, Leverage, Dan Likuiditas Terhadap Return Saham Dengan Nilai Tukar Sebagai Variabel Moderasi Pada Saham Lq-45. Journal of Business and Banking, 4(1), 67. https://doi.org/10.14414/jbb.v4i1.294

Tandelilin, E. (2010). Analisis investasi dan portofolio. Yogyakarta : BPFE., 2526.

Utami, W. B. (2014). Analisis Pengaruh Eva, Roa Dan Roe Terhadap Return Saham Pada Perusahaan Manufaktur Di Bursa Efek Jakarta Tahun 2006-2008. Jurnal Akuntansi Dan Pajak, 14(02), 1-19. https://doi.org/10.29040/jap.v14i02.72

Wahyuati, A., \& Septiana, F. E. (2016). Pengaruh Rasio Keuangan Terhadapreturn Saham Pada Perusahaan Manufaktur. Jurnal Ilmu \& Riset Manajemen, 5(1), $1-21$.

Wiagustini, N. L. P. (2010). Dasar-Dasar Manajemen Keuangan. Cetakan Pertama.Denpasar: Udayana Univeristy Press, 53(9), 1689-1699. https://doi.org/10.1017/CBO9781107415324.004

Wijesundera, A. A. V. I., Weerasinghe, D. A. S., Krishna, T. P. C. R., 
Ni Putu Alma Kalya Almira, Return On Asset, Return...

Gunawardena, M. M. D., \& Peiris, H. R. I. (2016). Predictability of stock returns using financial ratios: empirical evidence from Colombo stock exchange. Kelaniya Journal of Management, 4(2), 44. https://doi.org/10.4038/kjm.v4i2.7500 